\title{
Bipolaris sorokiniana: A POTENTIAL INDIGENOUS PLANT PATHOGEN TO CONTROL GOOSEGRASS (Eleusine indica) IN OIL PALM PLANTATIONS
}

\author{
MAIZAN ISMAIL*; ABD SHUKOR JURAIMI**; ABU SEMAN IDRIS*; MOHD HEFNI RUSLI*; RAJA \\ ZULKIFLI RAJA OMAR* and MOHD NAQIUDDIN*
}

\begin{abstract}
Indigenous plant pathogens, namely Bipolaris sorokiniana, Phoma herbarum and Curvularia aeria, were evaluated in the nursery to assess their potential of controlling goosegrass (Eleusine indica). Two experiments were conducted, which involved pathogenicity test and host range test. The pathogenicity test showed that B. sorokiniana was more pathogenic to $\mathrm{E}$. indica compared to $\mathrm{P}$. herbarum and $\mathrm{C}$. aeria.

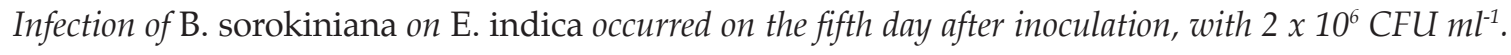
On the Day 35 after treatment, B. sorokiniana caused $94 \%$ disease severity, the highest damage compared to the other two fungal plant pathogens. The increase in disease severity affected E. indica's growth, causing dry weight losses of up to $28.5 \mathrm{~g}$, which was significantly lower than the dry weight of $\mathrm{E}$. indica treated with C. aeria $(39.5 \mathrm{~g})$ and untreated control $(39.2 \mathrm{~g}$ ). Nevertheless, B. sorokiniana did not infect oil palm seedlings. In other host plants, such as tomato, lady finger, sweet corn, chives, banana, eggplant, chili, sweet potato, Napier grass and spinach, B. sorokiniana only caused mild disease severity ranging from $10 \%$ to 20\%. Therefore, this study suggests that B. sorokiniana may have the potential to be used as a biological control agent for $\mathrm{E}$. indica in oil palm plantations.
\end{abstract}

\section{Keywords: weed biocontrol, Bipolaris sorokiniana, Eleusine indica.}

Date received: 12 February 2019; Sent for revision: 22 February 2019; Accepted: 20 May 2019.

\section{INTRODUCTION}

Weed can be described as any undesirable plant growing in undesirable places, especially in the planting areas of valuable crop plants. Weeds are classified according to their groups, such as grasses, broadleaves, ferns, sedges and epiphytes. They

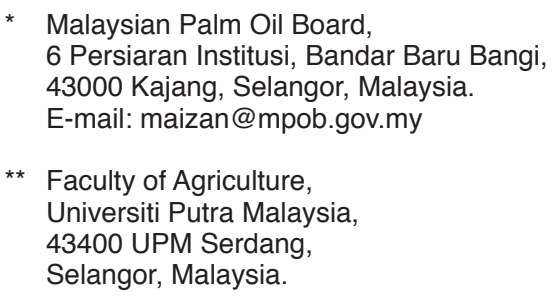

grow aggressively and compete with the main crops for light, nutrients, water and space to survive. Most weeds survive in extreme weather conditions and disperse seeds through wind, water, and soil.

Goosegrass (Eleusine indica), is a weed ranked as the fifth among the 10 worst weeds in the world. The species originated in Asia and represents one of the most notorious grass weeds in crops around tropical and temperate regions of the world. It is an annual species with an average production per plant of approximately 40000 seeds in pure stands (Kissman and Groth, 1991). The species is a serious weed in 42 countries and is frequently listed as a dominant weed species in farming systems which lack shading, for it grows vigorously and produce abundant seedlings (Holm et al., 1977). In Malaysia, 
E. indica could be found in orchards, oil palm plantations and vegetable farms (Barnes and Chan, 1990).

The E. indica is a noxious weed and the most destructive grass in oil palm plantations (Matthews, 1998). It was found to be the most prevalent grass $(82.2 \%)$ in immature oil palm plantations throughout Malaysia (Maizatul-Suriza and Idris, 2012). The weed competes strongly with oil palm for nutrients, water, light, and space (Holm et al., 1977). It could also affect oil palm growth and yield in the long-term by disrupting the economic life cycle of oil palm (Kuan et al., 1991). In addition, plantation management may be disrupted by the infestation of weed, as it could potentially host pests and diseases in oil palm plantations (Oudhia, 2004).

Herbicide application in controlling the weed population has been commonly practiced by farmers and planters for many years because it has been manually and conventionally difficult to control weed growth. In tropical countries, weed management is laborious, as the weather promotes the growth of weeds. Therefore, herbicides are widely used to suppress the growth of weeds in oil palm and rubber plantations (Chuah and Ismail, 2010).

The active pesticide ingredients used in Malaysia were about 39407 t in 2006 and 49199 t in 2016 (FAOSTAT, 2019) for effective weed control in oil palm and rubber plantations, as well as in direct-seeding rice farming (Jabran and Chauhan, 2015). These statistics represented an annual growth rate of $3.1 \%$ over the past 10 years for the nominal amount of agricultural pesticides used in the country. Among the various chemicals used in agriculture, herbicide had the largest usage, with $83 \%$ reported in 2014 (FAOSTAT, 2019). The common problems associated with conventional herbicides are related to their inherent ability to kill plants, harm non-target vegetation, and cause crop injury (Sherwani et al., 2015). The continuous use of some chemical herbicides has resulted in the manifestation of herbicide resistance in more than 140 weed species and thousands of crop fields worldwide (Heap, 1997). The presence of E. indica biotypes with resistance to some groups of herbicides is likely to become a concern (Chuah and Ismail, 2010). The first case of glyphosateresistant E. indica has been reported in orchards in Teluk Intan, Perak, Malaysia, in 1998 (Lim and Ngim, 2000). In comparison to the more susceptible E. indica, the 'Teluk Intan' biotype was found to be 8- to 12-fold resistant to glyphosate. Application of glyphosate at $5760 \mathrm{~g}$ salt ha ${ }^{-1}$ had only managed to control $25 \%$ of the Teluk Intan biotype E. indica (Lim and Ngim, 2000).

As weed is resistant to conventional chemical herbicides, researchers tend to investigate on the more environmental-friendly alternative methods of controlling weed. Research on the use of indigenous pathogens as bioherbicides has begun since 1940s (Wilson, 1969; Julien and Griffiths, 1998).

The use of bioherbicide is deemed to be an economical, effective and environmental-friendly method of controlling weed. Bioherbicide could reduce the dependency on chemical herbicides, delay the development of herbicide-resistant weed population, and reduce the risk of herbicide contamination to the environment. Bioherbicide is a long-term solution, which is most effective as part of an integrated weed management approach. It simply aims to reunite weeds with their natural enemies and achieve sustainable weed control (Barratt et al., 2018).

Examples of successful bioherbicide applications in controlling weed always involve indigenous plant pathogens. Fungal herbicides, applied by spraying them to targeted weeds, will suppress weed growth and maintain crop survival for a long period of time. Conventional chemical herbicides need to be applied repeatedly to suppress weed growth and they may harmfully affect the environment. In contrast, fungal herbicides could initiate diseases in weeds by producing phytotoxins, eventually killing the weeds within three to five weeks after inoculation (Hoagland, 2000).

The identified plant pathogens are usually easily cultured on artificial media such as potato dextrose agar (PDA), Oxoid, before mass-produced as an inoculum. They are able to produce abundant mycelia, which are stable in storage, less prone to mutation, tolerant to variation in temperature, and effective under field conditions (Charudattan, 1988; Daniel et al., 1973). Bioherbicide may be incorporated into on-going integrated weed management programmes for more efficient weed management (Robert, 2005). Searching for new bioherbicides for weed control in oil palm plantations is in line with Kushairi et al. (2018), suggesting that integrated pest management and advance biotechnology, as well as good agricultural practices, could help boost oil palm yields for both plantations and smallholdings.

In Malaysia, studies on the development of indigenous plant pathogens as biocontrol agents for E. indica in oil palm plantations are limited. Only few plant pathogens have been identified with the potential of controlling E. indica. One such example is Phoma herbarum. To thrust the oil palm industry forward, synergising conventional and disruptive technologies at every level of oil palm supply chain in the production of new bioherbicides for controlling weed in oil palm plantations is desirable and essential (Kushairi et al., 2018). Hence, this current study evaluated the potential of three different indigenous plant pathogens isolated from E. indica, namely Bipolaris sorokiniana, P. herbarum, and Curvularia aeria, to control E. indica via artificial inoculation in order to develop a new bioherbicide. 


\section{MATERIALS AND METHODS}

\section{Experiment Sites}

Two nursery experiments were conducted to determine the effect of indigenous plant pathogens on E. indica. The first experiment was conducted in a glasshouse from September until October 2016, Farm 15 at the Faculty of Agriculture, Universiti Putra Malaysia, Serdang, Selangor, Malaysia $\left(2^{\circ} 59.056^{\prime} \mathrm{N}, 101^{\circ} 43.957^{\prime} \mathrm{E}\right)$. The climate was humid, with an average temperature of $26.8^{\circ} \mathrm{C}$ and abundant rainfall. The second experiment was conducted from January until February 2017 at the nursery, Malaysian Palm Oil Board (MPOB) located at Section 15, Bandar Baru Bangi, Selangor $\left(2^{\circ} 55.645^{\prime} \mathrm{N}, 101^{\circ} 45.967^{\prime} \mathrm{E}\right)$. The climate was also humid, with an average temperature of $27^{\circ} \mathrm{C}$ and abundant rainfall, averaging $157.5 \mathrm{~mm}$ per month during the experiment.

\section{Experiment 1: Pathogenicity Test}

Planting material. Five emerging seedlings of E. indica were planted individually in each of the total 80 pots used for the experiment. Each pot (10 cm diameter $x 11.5 \mathrm{~cm}$ height) was filled with soil in the ratio of 3:2:1 (top soil: peat: sand). The pots were arranged in eight rows, with each row containing 10 pots. The distance between pots was $65 \mathrm{~cm}$ interrow, and $50 \mathrm{~cm}$ between rows (Figure 1). The age of E. indica used in the study was 14 days after planting.

Preparation of fungal inoculum. Young and actively growing B. sorokiniana, P. herbarum and C. aeria were individually cultured by adding 10 pieces of mycelial plugs ( $6 \mathrm{~mm}$ diameter) into a 1-litre conical flask containing $250 \mathrm{ml}$ autoclaved potato dextrose broth (PDB). The flask was then shaken at $150 \mathrm{rpm}$, continuously for 15 days at $28^{\circ} \mathrm{C}$. The mycelium was homogenised using a homogeniser (IKA T25 digital ULTRA TURRAX, Germany) at $10000 \mathrm{rpm}$ for $15 \mathrm{~min}$. The number of colonyforming unit (CFU) per $\mathrm{ml}$ was determined on PDA after five days of incubation at $25^{\circ} \mathrm{C}$ by using serial dilution method. The concentration of mycelial suspension for each tested fungus was adjusted by diluting with water to $2 \times 10^{6} \mathrm{CFU} \mathrm{ml}{ }^{-1}$ containing $0.01 \%$ Tween 20 .

Treatments and inoculation methods. Four treatments were assessed in this experiment, as shown in Table 1. For each treatment, a group of 20 pots containing E. indica was inoculated by spraying method using a 2-litre hand-held pressure sprayer. Each pot was sprayed with $10 \mathrm{ml}$ of fungal inoculum. The treated plants were enclosed with transparent plastic bag ( $44 \mathrm{~cm}$ length $\times 31 \mathrm{~cm}$ width) and sealed for $24 \mathrm{hr}$ to allow the fungus to infect the plants.
For the control, the plants were sprayed with sterile distilled water. The experiment was conducted for 35 days, using Completely Randomised Design (CRD) with 20 replications.

TABLE 1. TREATMENT IN THE STUDY

\begin{tabular}{cl}
\hline Treatment & \multicolumn{1}{c}{ Types of fungal pathogen } \\
\hline 1 & B. sorokiniana containing $0.01 \%$ Tween 20 \\
2 & P. herbarum containing $0.01 \%$ Tween 20 \\
3 & C. aeria containing $0.01 \%$ Tween 20 \\
4 & Control \\
\hline
\end{tabular}

Disease severity. Disease severity was rated at fiveday intervals after the application of treatment. The level of severity was rated based on the rating scale as described by Kadir and Charudattan (2000) in Table 2, with a slight modification. The rating scale was analysed using the following formula:

$$
\mathrm{DS}=\sum \frac{\left(\begin{array}{c}
\text { Severity rating } \mathrm{x} \\
\text { Number of plants in that rating }
\end{array}\right)}{\text { Total number of plants } \mathrm{x} \text { highest rating }} \times 100 \%
$$

TABLE 2. DISEASE SEVERITY SCALE

\begin{tabular}{cc}
\hline Disease scale & Leaf area damaged $(\%)$ \\
\hline 0 & 0 \\
1 & $1-10$ \\
2 & $11-20$ \\
3 & $21-30$ \\
4 & $31-40$ \\
5 & $41-50$ \\
6 & $51-60$ \\
7 & $61-70$ \\
8 & $71-80$ \\
9 & $81-90$ \\
10 & $91-100$ \\
\hline
\end{tabular}

Dry weight assessment of E. indica. At the end of the experiment, the dry weight of $E$. indica was assessed. The shoots in the experimental pots were cut and dried at $80^{\circ} \mathrm{C}$ for $72 \mathrm{hr}$ in a drying oven, Memmert, Germany (Mandal et al., 2014). The dried plant samples were weighed using electronic balances UX6200H Shimadzu, Japan.

Statistical analysis. The dry weight of treated E. indica infected by the fungal pathogens was analysed using one-way analysis of variance (ANOVA). Means was separated using Tukey's Test at $\mathrm{P}=0.05$.

\section{Experiment 2: Host Range Test}

Planting material. Eleven types of host plants were used in this experiment, comprising tomato, lady finger, sweet corn, chive, banana, eggplant, chilli, 
sweet potato, Napier grass, spinach and oil palm seedlings; additionally, E. indica was used as the control. They were all grown under a $70 \%$ shaded nursery and maintained at $26^{\circ} \mathrm{C}$ to $34^{\circ} \mathrm{C}$. E. indica was established using seeds collected from the field and transplanted in polybags $(24 \mathrm{~cm}$ width $\times 34 \mathrm{~cm}$ height) filled with a mixture of soil, sand, and peat in the ratio of 2:1:1, respectively. Tomato, lady finger, sweet potato, eggplant, chilli and spinach were established from seeds and transplanted in the same type of polybags containing the same soil mixture for seven days after germination and left to grow for two weeks. Chives, sweet potato and Napier grass were established from stem cuttings and transplanted in polybags and left to grow two weeks before treatment. Banana was established using threeweek old tissue cultured seedlings, transplanted in polybags. For oil palm, three-month old commercial seedlings in polybags were used. Plants' age varied depending on the species, but each plant species was at a young developmental stage for treatment. Host plants were selected based on their potential to be used as integration crops, with oil palm following previous research findings (Raja Zulkifli et al., 2010; Suboh and Roslan, 2004). The distance between polybags was $55 \mathrm{~cm}$ inter-row and $50 \mathrm{~cm}$ between rows.

Preparation of fungal inoculum. Only one plant pathogen was used in this experiment, namely $B$. sorokiniana. The selection was based on results from Experiment 1, which indicated that B. sorokiniana was the most potential biocontrol agent for E. indica compared to $P$. herbarum and $C$. aeria. The fungal inoculum was prepared using the same method as described in Experiment 1.

Inoculation method and disease severity. Each host plant was sprayed to run-off $(10 \mathrm{ml})$ with $2 \times 10^{6} \mathrm{CFU}$ $\mathrm{ml}^{-1}$, containing $0.01 \%$ Tween 20 of B. sorokiniana using a 2-litre hand-held pressure sprayer. Control plants were sprayed with sterile distilled water. The treated plants were arranged in Randomised Complete Block Design (RCBD) with 10 replications (Figure 2). Disease severity was rated at five-day intervals after application of treatment, following the method described in Experiment 1. The experiment was conducted for 40 days.

\section{RESULTS}

\section{Experiment 1 - Pathogenicity Test}

Figure 3 shows the percentage of disease severity of E. indica after being inoculated with B. sorokiniana, P. herbarum, and C. aeria at $2 \times 10^{6} \mathrm{CFU} \mathrm{ml}^{-1}$ containing $0.01 \%$ Tween 20 . Results showed that B. sorokiniana was more pathogenic to E. indica than the other two plant pathogens, $P$. herbarum and $C$. aeria. At five days after treatment (DAT), B. sorokiniana caused the highest disease severity at $10 \%$, compared to P. herbarum (4\%) and C. aeria (8\%). However, at 10 DAT, disease severity by B. sorokiniana (18\%) had not increased significantly compared to other treatments with P. herbarum $(30 \%), C$. aeria $(30 \%)$ and the control (22\%). The disease infection for all tested fungal pathogens increased at 20 DAT, with the highest rating shown by B. sorokiniana $(60 \%)$, followed by P. herbarum (50\%), C. aeria (54\%) and the control (40\%). At 35 DAT, the percentage of disease severity of $E$. indica treated with $B$. sorokiniana and P. herbarum was $94 \%$ and $90 \%$, respectively. At this stage, the severity level caused by both plant pathogens was higher compared to C. aeria (66\%), and the control $(56 \%)$. Although this experiment suggested that $B$. sorokiniana and $P$. herbarum have a potential of controlling E. indica, B. sorokiniana is chosen for further study because $P$. herbarum is currently under investigation by another group of

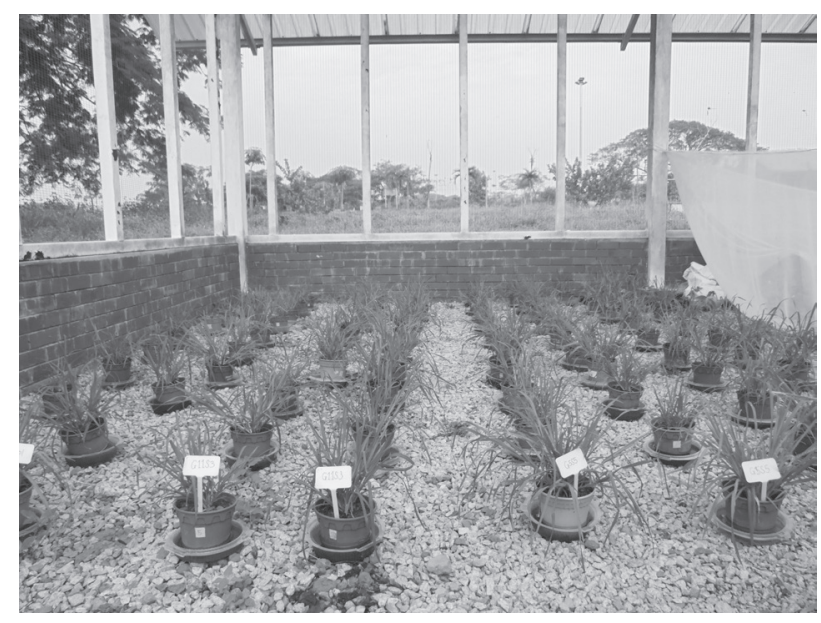

Figure 1. The experimental layout for Experiment 1.

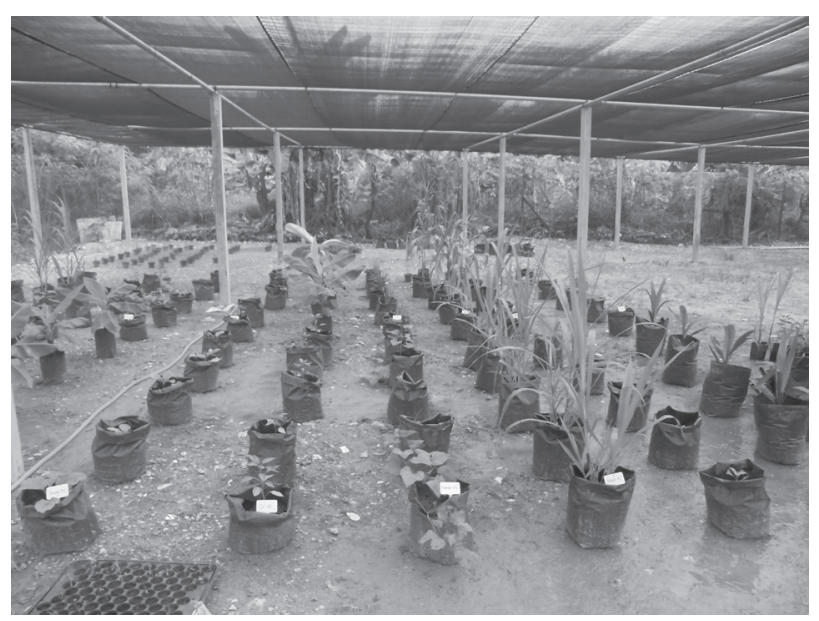

Figure 2. Layout of host plants used in Experiment 2. 
researchers at the Ganoderma Disease Research of Oil Palm (GanoDrop) Unit at MPOB. Meanwhile, C. aeria developed the lowest disease severity to E. indica in comparison to B. sorokiniana and $P$. herbarum. Therefore, $P$. herbarum and C. aeria were not evaluated further in Experiment 2. Figure 4 shows the symptom of disease on E. indica caused by B. sorokiniana, P. herbarum and C. aeria.

The effects of disease caused by plant pathogens in reducing the dry weight of E. indica was also determined. The study recorded that the dry weight of E. indica inoculated with $B$. sorokiniana at $2 \times 10^{6} \mathrm{CFU}$ $\mathrm{ml}^{-1}$ was $28.5 \mathrm{~g}$; this was significantly lower $(\mathrm{P}<0.05)$ compared to E. indica inoculated with C. aeria (39.5 g) and the control (39.2 g) (Figure 5). However, the dry weight of $E$. indica inoculated with $B$. sorokiniana and $P$. herbarum did not demonstrate any significant difference. The lowest dry weight of $E$. indica yielded by the plant pathogen $B$. sorokiniana suggested that the fungus was able to inhibit the growth of E. indica.

\section{Experiment 2 - Host Range Test}

The disease severity of tested host plants treated

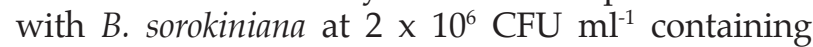
$0.01 \%$ Tween 20 is shown in Figure 6. The level of disease severity of lady finger, eggplant, sweet potato, Napier grass and spinach, treated with B. sorokiniana was below $10 \%$ throughout the experiment. At 10 DAT, the fungus infected chives up to $36 \%$ severity, but the plant was able to recover from the disease after 10 days of inoculation, and the disease remained localised without any infestation to other new developing leaves.
Moderate disease severity below 20\% was observed for tomato, sweet corn and banana. For oil palm, none of the seedlings was infected by B. sorokiniana by the end of the experiment. For E. indica, the disease severity increased from $23 \%$ at $5 \mathrm{DAT}$, to $60 \%$ at $10 \mathrm{DAT}$, then rapidly increased from 25 DAT to 40 DAT to peak at $79 \%$. This study suggested that the plant pathogen $B$. sorokiniana was highly pathogenic and host-specific to E. indica.

\section{DISCUSSION}

B. sorokiniana, P. herbarum, and C. aeria are indigenous plant pathogens isolated from E. indica (Maizatul et al., 2017; Rusli et al., 2015). The fungi, which cause disease to a wide range of hosts in Poaceae, are significant pathogens classified as high temperature fungi with the ability to survive in extreme weather and temperature. B. sorokiniana is known as a causal agent of common root rot disease, leaf spot disease, seedling blight, head blight drum, and black print among wheat and barley (Zhong and Steffenson, 2001; Mathre et al., 2003; Meldrum et al., 2004). The disease, which was also reported on other grasses (Kumar et al., 2002), was listed in the group of necrotrophic and highly virulent pathogens (Berbee et al., 1999). P. herbarum was reported to have been infecting cherry palm with leaf spot disease for the first time in Chiang Mai Province, Thailand (Kumla et al., 2016), whereas incidence of $C$. aeria infection was reported to have been causing rice leaf spot disease in Malaysia. C. aeria was listed in the group of mild plant pathogens (Kusai et al., 2015).

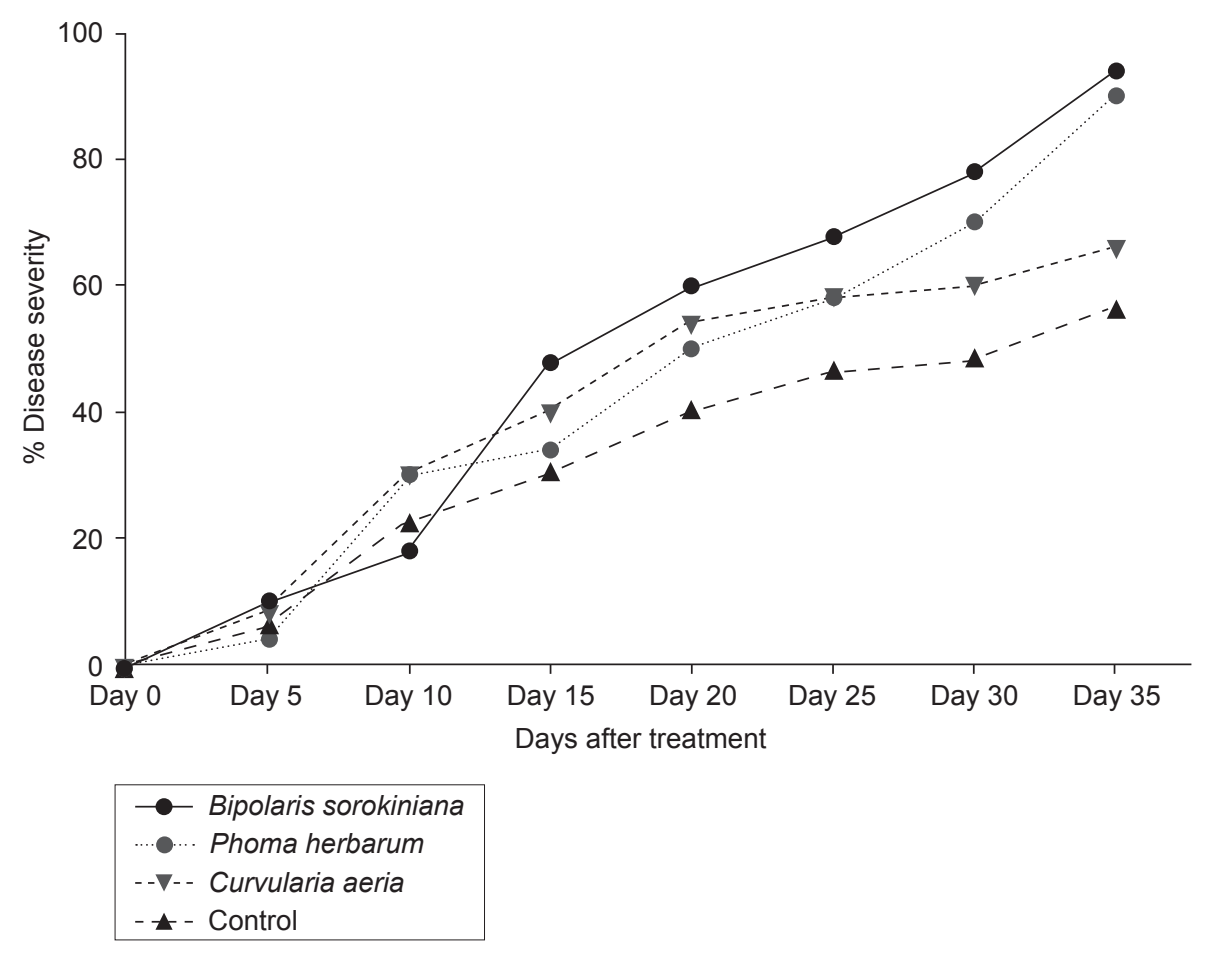

Figure 3. Percentage of disease severity of Eleusine indica inoculated with different indigenous fungal plant pathogens. 

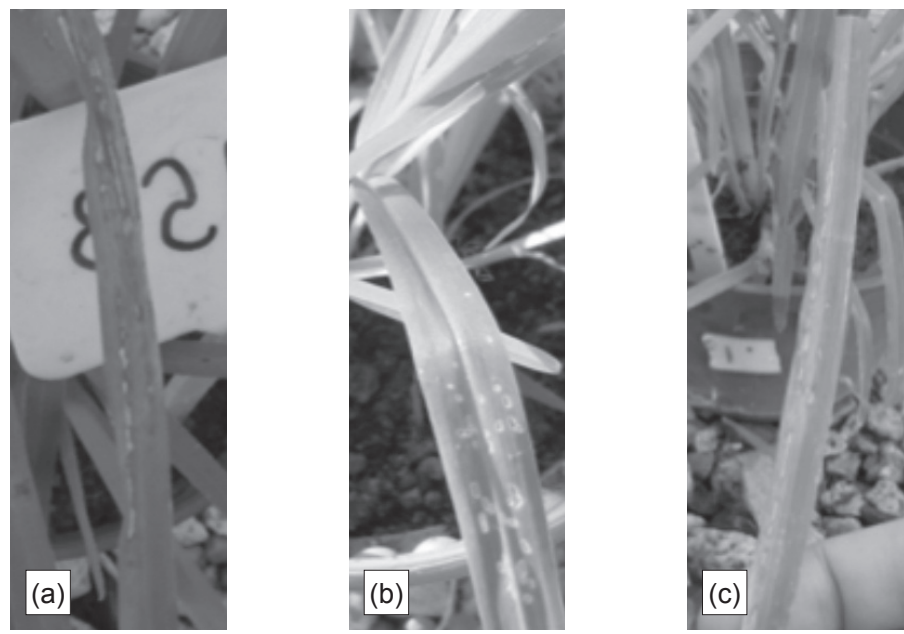

Figure 4. Symptom on Eleusine indica inoculated with (a) Bipolaris sorokiniana, (b) Phoma herbarum, and (c) Curvularia aeria.

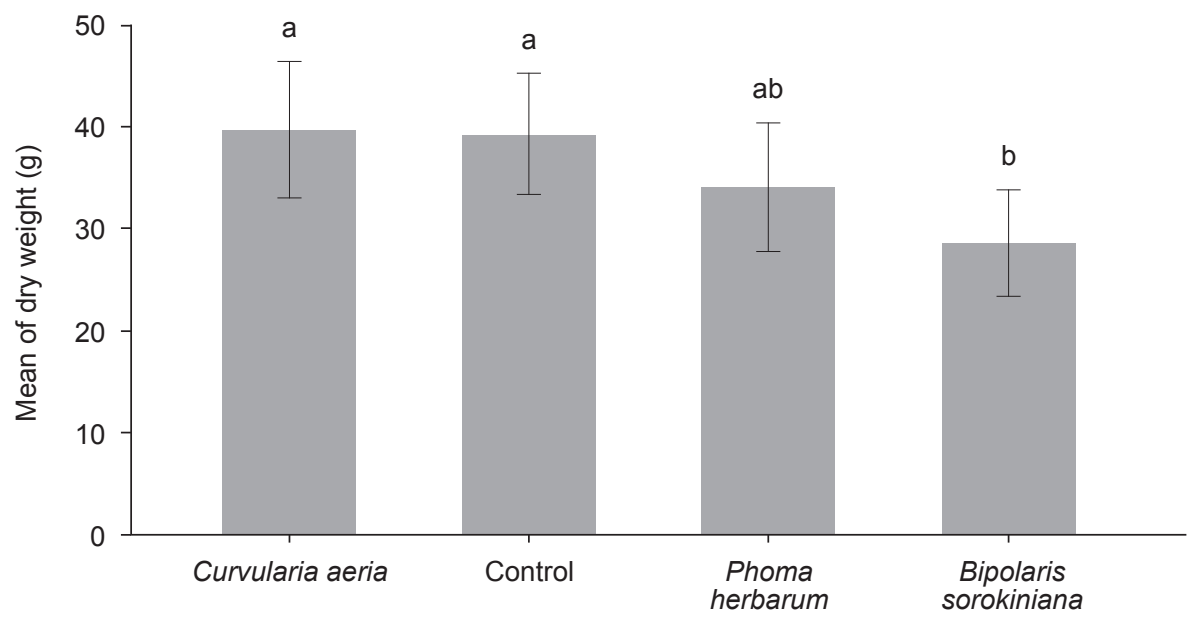

Fungi treatment

Mean dry weight
Conidial concentration for fungi: $2 \times 10^{6}$ conidial $\mathrm{ml}^{-1}+0.01 \%$ Tween 20
Control: Distilled water $+0.01 \%$ Tween 20

Figure 5. Mean dry weight of Eleusine indica treated with different fungal plant pathogens. Means followed by the same letters are not significantly different at $P=0.05 \%$ after Tukey's test.

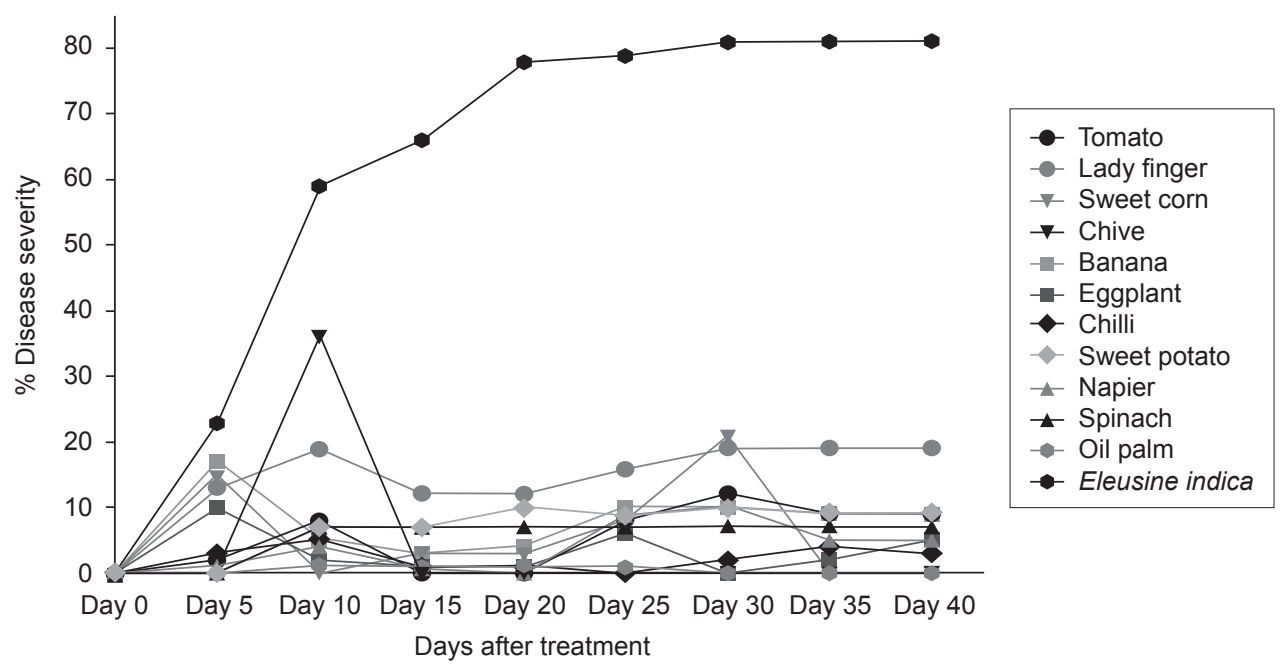

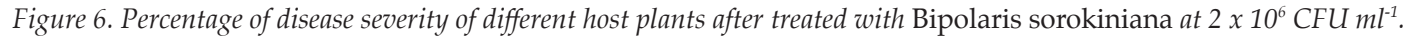


Observation on the high percentage of disease severity caused by $B$. sorokiniana and $P$. herbarum was supported by Maizatul et al. (2017), suggesting that both pathogens could damage the whole plant; Rusli et al. (2015) also reported that P. herbarum was highly pathogenic to E. indica. Although these two types of plant pathogens were isolated from the diseased stems, the fungi had been able to cause lesions on the E. indica leaves (Maizatul et al., 2017). Meanwhile, mainly due to the naturally occurring infestation of leaf-spotting pathogen, infection in the control group, which severely damaged the leaves, recorded up to $50 \%$ disease severity. This was supported by the research on biological control for E. indica in South Carolina, which identified the fungus Bipolaris setaria as the fungal leaf-spotting pathogen that had naturally infected E. indica in field plots in summer, whereas the fungal pathogen Piricularia frisea had infected E. indica in a greenhouse in spring (Figliola et al., 1988).

The diseased shoots of weed infected by bioherbicide agents had reduced the weed biomass at the end of the experiment. In the experiment, treatment with $B$. sorokiniana had resulted in the lowest dry weight of E. indica shoots, indicating that the fungus had effectively suppressed the growth of E. indica. New leaves were inhibited from developing, thus reducing the biomass weight through lesion, wilting, and drying of the leaves. Initial symptoms of $B$. sorokiniana infection on the leaves of E. indica were observed based on the appearance of darkbrown elliptical flecks, developing $24 \mathrm{hr}$ after inoculation. Lesions expanded to large areas of the leaf. Expanding lesions were deep brown with a chlorotic halo and turned the leaf to yellow before wilting and drying, causing the leaf to die. Drying of the leaves started from the bottom part of E. indica and moved up to the crown region. The infected plants were commonly smaller compared to the control plants. Reduction in dry weight was also reported on the weed Cyperus rotundus when treated with the fungus Dactylaria higginsii by spraying with $10^{6}$ conidia $\mathrm{ml}^{-1}$. Cyperus rotundus is the world's worst weed, infecting rice, sugar cane, cotton, corn and vegetables (Kadir and Charudattan, 2000).

To ensure that candidates of plant pathogens for bioherbicide do not affect other important plants, host range test is a prerequisite. This study provided the assessment of the host range test for B. sorokiniana. The results demonstrated that B. sorokiniana was a specific plant pathogen which caused severe disease only to E. indica. The fungus could also infect other plants, though the impacts would be considerably mild since it only caused $20 \%$ to $25 \%$ disease severity to other host plants. More importantly, B. sorokiniana did not infect oil palm seedlings. This study proved that $B$. sorokiniana has a potential to be used as a biocontrol agent for E. indica in oil palm plantations.

\section{CONCLUSION}

B. sorokiniana has a potential as a biocontrol agent for E. indica. The treated E. indica plants were severely damaged with suppressed growth and reduced the biomass. The host plants test showed that B. sorokiniana was a specific plant pathogen, only affecting $E$. indica and not causing disease to nontarget crops. More importantly, the fungus did not infect oil palm seedlings, indicating that B. sorokiniana may be used as biocontrol agent for $E$. indica in oil palm plantations. Further study is required to investigate the efficacy of $B$. sorokiniana under conditions in the field. Successful development of weed biocontrol will reduce environmental pollution, such as ground water and soil contamination.

\section{ACKNOWLEDGEMENT}

This research was financially supported by MPOB. The authors wish to thank the Director-General of MPOB for permission to publish this work. This research was jointly conducted between MPOB and the Faculty of Agriculture, Universiti Putra Malaysia. We are also grateful to the staff at the GanoDROP Unit, MPOB for their co-operation and assistance throughout this project.

\section{REFERENCES}

Barnes, D E and Chan, L G (1990). Common Weeds of Malaysia and their Control. Kuala Lumpur: Ancom Berhad. 349 pp.

Barratt, B I P; Moran, V C; Bigler, F and Van Lenteren, J C (2018). The status of biological control and recommendations for improving uptake for the future. BioControl, 63(1): 155-167.

Berbee, M; Pirseyedi, M and Hubbard, S (1999). Cochliobolus phylogenetics and the origin of known, highly virulent pathogens, inferred from ITS and glyceraldehyde-3-phosphate dehydrogenase gene sequences. Mycologia, 91: 964-977.

Charudattan, R (1988). Inundative control of weeds with indigenous fungal pathogen. Fungi in Biological Control Systems (Burge, M N ed.). Manchester University Press, Manchester, England. p. 88-110.

Chuah, T S and Ismail, B S (2010). The status of weed resistance in plantation crops of Malaysia. The Planter, 86 (1014): 615-620.

Daniel, J T; Templeton, G E; Smith, R J Jr and Fox, W T (1973). Biological control of Northern Jointvetch in rice with an endemic fungal disease. Weed Sci., 21: 303-307. 
FAOSTAT (2019). http://www.fao.org/faostat/ en / \# data/RP/, accessed on 26 March 2019.

Figliola, S S; Camper, N D and Ridings, W H (1988). Potential biological control agents for goosegrass (Eleusine indica). Weed Science, 36(6): 830-835.

Heap, I M (1997). The occurrence of herbicideresistant weeds worldwide. Pesticide Science, 51(3): 235-243.

Hoagland, R E (2000). Bioherbicides: Phytotoxic natural products. ACS Symposium Series (Vol. 774). Washington, D C. p. 72-90.

Holm, L G; Plucknett, D L; Pancho, J V and Herberner, J P (1977). The World's Worst Weeds. University Press of Hawaii, Honolulu, USA. 609 pp.

Jabran, Kand Chauhan, BS(2015). Weed management in aerobic rice systems. Crop Prot., 78: 151-163.

Julien, M H and Griffiths, M W (1998). Biological Control of Weeds: World Catalogue of Agents and their Target Weeds. $4^{\text {th }}$ ed. CAB International. Wallingford, Oxon, United Kingdom. 223 pp.

Kadir, J and Charudattan, R (2000). Dactylaria higginsii, a fungal bioherbicide agent for purple nutsedge (Cyperus rotundus). Biological Control, 17: 113-124.

Kissman, K G and Groth, D (1991). Plantas Infestantes Enocivas. Sao Paulo, BASF.

Kuan, CY; Ann, L S; Ismail, A A; Leng, T; Fee, C G and Hashim, K (1991). Crop loss by weeds in Malaysia. Proc. of the Third Tropical Weed Science Conference. Kuala Lumpur. Malaysian Plant Protection Society. p. 1-21.

Kumar, J; Schafer, P; Huckelhoven, R; Langen, G; Baltruschat, H; Stein, E; Nagarajan, S and Kogel, K H (2002). Bipolaris sorokiniana, a cereal pathogen of global concern; cytological and molecular approaches towards better control. Molecular Plant Pathology, 3(4): 185-195.

Kumla, J; Suwannarach, N and Lumyong, S (2016). First report of Phoma leaf spot disease on cherry palm caused by Phoma herbarum in Thailand. Canadian J. Plant Pathology, 38(1): 103-106.

Kusai, N A; Azmi, M M Z; Zulkifly, S; Yusof, M T and Zainudin, N (2016). Morphological and molecular characterization of Curvularia and related species associated with leaf spot disease of rice in Peninsular Malaysia. Rendiconti Lincei, 27(2): 205-214.

Kushairi, A; Loh, S K; Azman, I; Hishamuddin, E; Ong-Abdullah, M; Mohd Noor Izzuddin, Z B; Razmah, G; Sundram, S and Ahmad Parveez, G K (2018). Oil palm economic performance in Malaysia and R\&D progress in 2017. J. Oil Palm Res. Vol. 30(2): 163-195.

Lim, J L and Ngim, J (2000). A first report of glyphosate-resistant goosegrass [Eleusine indica (L) Gaertn] in Malaysia. Pest Management Science, 56: 336-339.

Maizatul-Suriza, M and Idris, A S (2012). Occurrence of common weeds in immature plantings of oil palm plantations in Malaysia. The Planter, 88(1037): 537547.

Maizatul-Suriza, M; Idris, A S; Madihah, A Z and Rusli, M H (2017). Detached leaf assay for in vitro screening of potential biocontrol agents to control goosegrass weed (Eleusine indica). J. Oil Palm Res. Vol. 29(4): 562-569.

Mandal, M S H; Ali, M H; Amin, A K M R; Masum, S M and Mehraj, H (2014). Assessment of different weed control methods on growth and yield of wheat. International J. Agronomy and Agriculture Research, 5: 65-73.

Mathre, D E; Johnston, R H and Grey, W E (2003). Diagnosis of common root rot of wheat and barley. Plant Health Progress, 4(1): 11.

Matthews, C (1998). The introduction and establishment of a new leguminous cover crop, Mucuna bracteata under oil palm in Malaysia. The Planter, 74: 359-368.

Meldrum, S I; Platz, G J and Ogle, H J (2004). Pathotypes of Cochliobolus sativus on barley in Australia. Australasian Plant Pathology, 33: 109-114.

Oudhia, P (2004). Phyto-sociological studies of rainy wastelands weed with special reference to Parthenrium hysterophous L. in Raipur District (India). http: / / www. iprng. org/IPRNGtoandw15. htm. Asian J. Micro., Bio. and Environment Sciences, 3(1): 91-94.

Raja Zulkifli, R O; Wahid, O and Norkaspi, K (2010). Sweet potato production in oil palm plantation. MPOB Information Series No. 465: 4 pp.

Robert, J K (2005). The role of bioherbicides in weed management. Biopestic. Int. 1(3,4): 127-141. 
Rusli, M H; Sharifah Muzzaimah, S A; Maizatul Suriza, M and Idris, A S (2015). Powder formulation of Phoma herbarum as biological control of goose grass (Eleusine indica). MPOB Information Series No. 565: 4 pp.

Sherwani, S I; Arif, I A and Khan, H A (2015). Modes of action of different classes of herbicides. Herbicides, Physiology of Action and Safety. IntechOpen. DOI: 10.5772 / 61779.
Suboh, I and Roslan, A (2004). Integration of banana (berangan variety) with oil palm planted in double avenue system. MPOB Information Series No. 224: 4 pp.

Wilson, C L (1969). Use of plant pathogens in weed control. Annu. Rev. Phytopathol., 7: 422-434.

Zhong, S and Steffenson, B J (2001). Virulence and molecular diversity in Cochliobolus satious. Phytopathology, 91(5): 469-476.

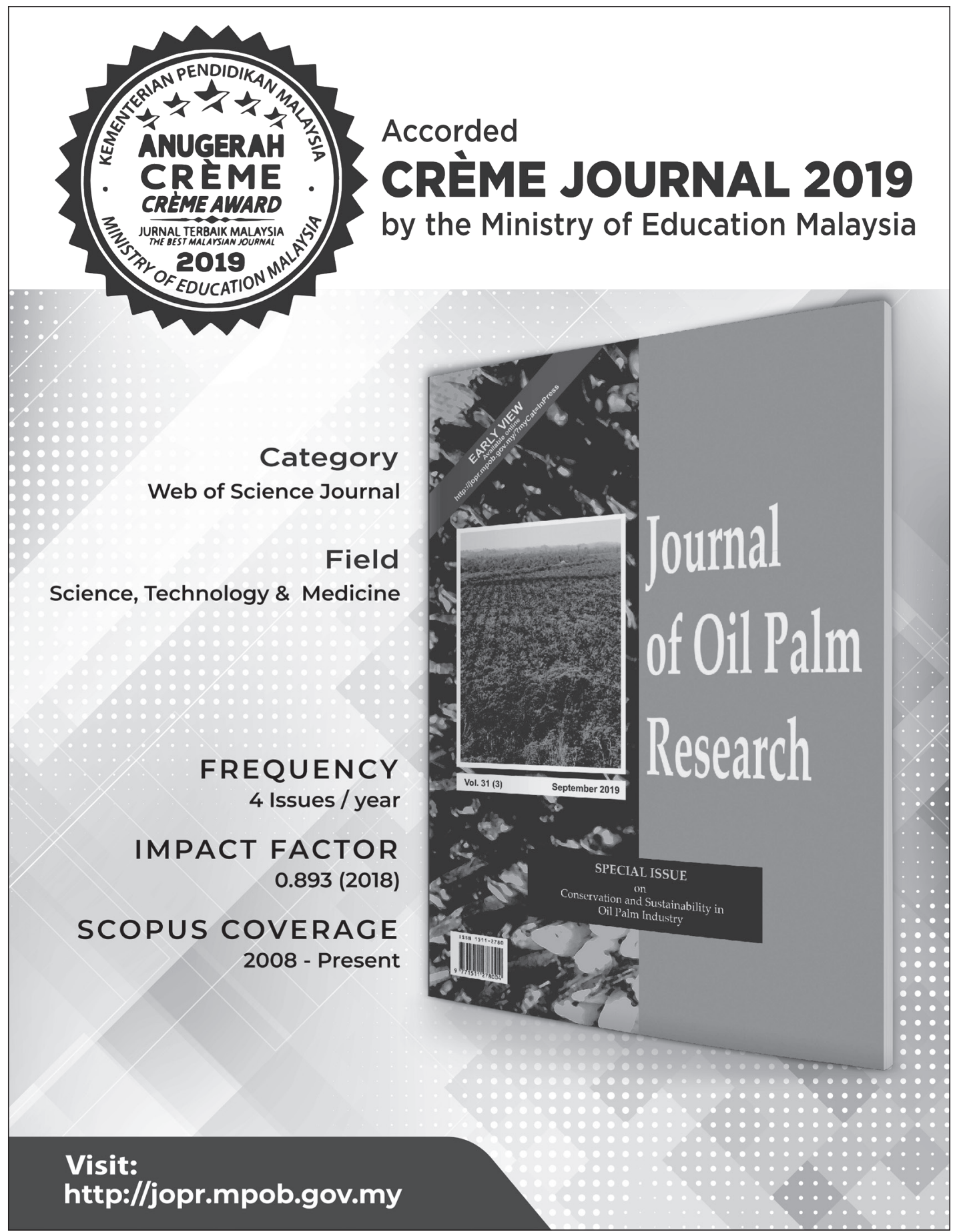

